А.М. Луцишин, Г.С. Степанов, І.А. Костюк

Наџіональний університет оборони Украӥни імені Івана Черняховського, Київ

\title{
ПРОБЛЕМИ ВИЗНАЧЕННЯ УПРАВЛІННЯ ПРОТИПОВІТРЯНОЮ ОБОРОНОЮ ПІД ЧАС ПРОВЕДЕННЯ ОПЕРАЦІЇ ЗБРОЙНИХ СИЛ
}

В статті розглянуто роль і місие протиповітряної оборони у системі стратегічних дій та ї̈ вплив на забезпечення обороноздатності держави. Вказані проблемні питання, які впливають на організацію та ведення протиповітряної оборони. Розглянуто протиріччя існуючих теоретичних підходів до управління протиповітряною обороною України з практичними можливостями ії реалізації. Причини їх виникнення та вплив на ефективність управління протиповітряною обороною. Особливістю питання, щьо розглядається в статті, є урахування умов управління протиповітряною обороною під час стратегічної операції збройних сил, яка має комплексний характер проведення, в основі якого покладено одночасне застосування міжвидових угруповань військ пов'язаних єдиною стратегічною метою. Розглянуто шляхи їх вирішення та визначені напрямки для подальшого дослідження з метою обтрунтування рекомендацій по підвищенню ефективності управління протиповітряною обороною у ході ведення операчії ЗС без зниження ефективності системи протиповітряної оборони держави.

Ключові слова: управління, ППО, система управління, ефективність управління, ВДО, критичні об 'єкти держави, органи управляння, пункти управління ППО.

\section{Вступ}

Постановка проблеми. На сучасному етапі розвитку теорії воєнного мистецтва домінує розвиток концепцій “мереже-центрічних" та “безконтактних” війн. Досягнення науки та техніки вплинуло на розвиток воєнних технологій. Підвищення вогневих, просторових, маневрених можливостей озброєння вимагає перегляду положень тактики та оперативного мистецтва. Елементи теоретичних напрацювань інтенсивно випробуються на практиці, під час останніх збройних конфліктів. Досягнення цілей збройного протиборства вирішується не за рахунок розгрому збройних сил, угруповань (живої сили та OBT) а за рахунок підриву економіки, порушення системи державного управління шляхом нанесення повітряно-космічних ударів по критичним об'єктам державного управління, економіки, знищення важливих військових об'єктів управління, логістики, ВПК, порушення об'єктів інфраструктури та комунікацій на просторі усієї держави, що здійснює спротив. Порівняльний аналіз змін особливостей війн, де застосовувалась повітряна компонента, наведено у табл. 1.

Таблиця 1

Порівняння особливостей війн IV - VI поколінь

\begin{tabular}{|c|c|c|c|c|c|c|}
\hline \multirow{3}{*}{$\begin{array}{c}\text { Покоління війн } \\
\text { (збройних } \\
\text { конфліктів) }\end{array}$} & \multicolumn{6}{|c|}{ Параметри порівняння } \\
\hline & \multirow{2}{*}{ Основне озброєння } & \multicolumn{3}{|c|}{ Основний вид протиборства } & \multirow{2}{*}{$\begin{array}{c}\text { Масштаб війни } \\
\text { (рівень) }\end{array}$} & \multirow{2}{*}{ Мета } \\
\hline & & суходіл & mope & повітря & & \\
\hline IV & $\begin{array}{c}\text { Автоматична та реакти- } \\
\text { вна зброя механіз. війсь- } \\
\text { ка, танки, авіація, авіа- } \\
\text { носці, підводні човни }\end{array}$ & $\begin{array}{l}\text { Операції } \\
\text { фронтів }\end{array}$ & $\begin{array}{l}\text { Морські } \\
\text { операції }\end{array}$ & $\begin{array}{c}\text { Повітряні } \\
\text { удари по } \\
\text { військах, } \\
\text { авіаційні бої }\end{array}$ & Стратегічний & $\begin{array}{c}\text { озгром ЗС противника } \\
\text { руйнування його еко- } \\
\text { ном. потенціалу, зміна } \\
\text { політичного устрою }\end{array}$ \\
\hline $\mathrm{V}$ & Ракетно-ядерна зброя & \multicolumn{3}{|c|}{ Ракетно-ядерний удар } & $\begin{array}{c}\text { Стратегічний, глоба- } \\
\text { льний, загроза заги- } \\
\text { белі цивілізації або } \\
\text { окремих континентів }\end{array}$ & $\begin{array}{l}\text { Цілі не досягаються - } \\
\text { сторона, яка застосо- } \\
\text { вує ядерну зброєю } \\
\text { знищується другою }\end{array}$ \\
\hline VI & $\begin{array}{c}\text { Високоточна зброя, } \\
\text { зброя на новітніх фізич- } \\
\text { них принципах, інфор- } \\
\text { маційна зброя, сили та } \\
\text { засоби РЕБ }\end{array}$ & $\begin{array}{l}\text { Спільна } \\
\text { повітря- } \\
\text { но- } \\
\text { морська } \\
\text { наземна } \\
\text { операція }\end{array}$ & $\begin{array}{c}\text { Спільна } \\
\text { повітряно- } \\
\text { наземна } \\
\text { морська } \\
\text { операція }\end{array}$ & \begin{tabular}{|c|} 
Повітряно- \\
космічна опе-- \\
рація із засто-- \\
суванням \\
звичайної збро
\end{tabular} & $\begin{array}{l}\text { Оперативно- } \\
\text { стратегічний }\end{array}$ & $\begin{array}{c}\text { Підрив економіки, } \\
\text { порушення системи } \\
\text { державного управління } \\
\text { підрив життєдіяльності } \\
\text { держави, знищення } \\
\text { військових об'єктів }\end{array}$ \\
\hline
\end{tabular}

Перспективний підхід до застосування ЗПН та їх наслідки дозволяють паралізувати функціонування сторони, що обороняється та досягти воєннополітичних цілей війни (збройного конфлікту) з збереженням бойового потенціалу наземного угруповання військ та найменшими економічними витратами і людськими втратами [2-7].
Як наслідок, протиповітряна оборона стала одним 3 основних стратегічних факторів які визначають рівень безпеки держави. Стан системи ППО один 3 факторів, який визначає їі обороноздатність. Протиповітряна оборона організовується у мирний час та здійснюється постійно, як у мирний час так i в особливий період. 
Для ефективного виконання завдань ППО держави залучаються визначені сили та засоби всіх видів 3С а також сили та засоби державних організацій та установ. Як наслідок, управління протиповітряною обороною є процес підвищеної складності, який повинен формувати цільовий управляючий вплив на суб'єкти управління в стислі терміни (у масштабі реального часу) та постійно здійснювати моніторинг за змінами всієї системи.

Проблема, щодо підвищення ефективності системи ППО має давню історію. ІІЇ вирішення як у СРСР так і в Україні вирішувалась шляхом реформування. Реформувались війська ППО, як вид ЗС. Правонаступником військ ППО та ВПС є Повітряні Сили Збройних Сил України, на які поклали відповідні завдання двох видів. Була створена інтегрована система управління, яка спроможна виконувати визначені завдання Повітряних Сил і усунула проблему управління силами та засобами частин ЗРВ, РТВ та авіації .

На теперішній час, остається актуальним питання - підвищення ефективності протиповітряної оборони міжвидових угруповань Збройних Сил під час їх спільного оперативного застосування у ході ведення стратегічної операції.

Одна $з$ важливих проблем, що впливає на ефективність протиповітряної оборони міжвидових угруповань Збройних Сил це забезпечення ефективного управління силами та засобами ППО ПС ЗС України та ППО СВ ЗС України під час ведення стратегічної операції ЗС України та виконання завдань протиповітряної оборони держави.

Зазначена проблема обумовлена протиріччям існуючих теоретичних підходів до організації управління протиповітряною обороною України 3 практичними можливостями її реалізації. Особливістю підходу до аналізу зазначеної проблеми, в статті $\epsilon$ урахування вимог (умов) до проведення виду стратегічних дій - операції ЗС. Операція ЗС має комплексний характер проведення, в основі якого покладено одночасне застосування міжвидових угруповань військ, пов'язаних єдиною стратегічною метою.

На даний час підвищення ефективності управління протиповітряною обороною у ході ведення операції ЗС приводить до зниження ефективності системи управління протиповітряної оборони держави і як наслідок, зниження загальної системи протиповітряної оборони.

Аналіз останніх досліджень і публікацій. Державна програми розвитку Збройних Сил України на період до 2020 року передбачає заходи розвитку системи управління, удосконалення системи пунктів управління з обладнанням їх засобами сучасної автоматизації [1] .

Періодичні видання [1-8] висвітлюють погляди на розвиток здійснення управління міжвидовими угрупованнями військ у ході їх застосування, угру- повання ППО розглядається тільки для здійснення прикриття військ без виконання завдань ППО держави. В [9-10] запропоновані шляхи підвищення ефективності системи управління ППО за рахунок удосконалення технічної складової - АСУ. В 9 13] представлено методичний підхід щодо оцінки ефективності системи управління силами та засобами ППО. У виданнях $[14,16,17]$ розглядається побудова угруповання військ на принципах “мережоцентричної" концепції. Матеріал видання [15] розглядає основні показники для оцінки ефективності функціонування системи ППО на сучасному етапі. У роботі $[10,13,18]$ пропонується до розгляду удосконалення показників для оцінки ефективності структури системи управління. Таким чином можливо констатувати, що певна робота по вирішенню проблеми ведеться. Але існує необхідність в узагальнені виявлених проблем, їх деталізації з наступним виявленням причин їх існування для подальшого визначення шляхів їх вирішення.

Метою статті с розгляд проблемних питань управління протиповітряною обороною України в операції Збройних Сил та шляхів щодо їх вирішення.

\section{Виклад основного матеріалу}

Якісне функціонування системи управління ППО держави, як підсистема управління 3С, є основним фактором ефективного виконання завдань протиповітряною обороною під час:

підготовки держави до відсічі збройної агресії;

ведення Збройними Силами стратегічної операції щодо відбиття вторгнення;

виконання різнопланових завдань оперативними та тактичними угрупованнями військ (ОУВ, ОТУ) на головному та інших оперативних напрямах; відновлення та перегрупування військ.

Основу системи управління ППО держави складає система управління Повітряних Сил Збройних Сил. Їй властиві особливості функціонування, а саме: велика різноманітність різнорідних багатофункціональних об'єктів управління;

інтенсивні потоки неоднорідної за призначенням, складом, змістом та формою інформації;

висока швидкість зміни обстановки як при відбитті ударів ЗПН, так і при нанесенні повітряних ударів у ході проведення повітряної (протиповітряної) операції,

складна радіоелектронна обстановка;

багатоваріантність та висока динаміка змін стану, структури системи для забезпечення високої живучості та скритності функціонування; велика відстань між об'єктами управління; функціонування в реальному масштабі часу; обмежений термін на прийняття рішення в умовах недостатності і невизначеності інформації про обстановку [9, 10]. 
Постійне функціонування системи управління ППО в зазначених умовах забезпечує спроможність збройних сил виконати поставлені завдання. Під час функціонування, на кожний загрозливий вплив здійснюються ряд основних заходів: підготовка та організація роботи органів управління, розгортання відповідних пунктів управління силами та засобами ППО, обладнання (дообладнання) системою зв'язку та засобами автоматизації, організація роботи щодо підтримання матеріально-технічної основи в боєздатному стані (відновлення) та організація контролю за станом її бойової готовності і готовності до переходу вищі ступені функціонування.

Система управління ППО розгортається на базі діючого угруповання сил та засобів ППО ПС та нарощується у особливий період під час розгортання угруповання ППО держави. Вона забезпечує управління силами та засобами ППО для прикриття з повітря всі подальші заходи, які сплановані для відсічі збройної агресії.

Створення (посилення) міжвидових угруповань проводиться пізніше. Заходи їх розгортання, підготовки до бойових дій здійснюються під протиповітряним прикриттям в загальній системі ППО уже створеного угруповання ПС.

Не спроможність системи управління ППО виконати визначені завдання, може привести у подальшому до фатальних наслідків під час застосування міжвидових угруповань військ.

У разі залучення частини сил та засобів авіації і ППО ПС елементів системи управління ПС (ПУ, засоби зв'язку і автоматизації) до виконання завдань за планами ОУВ, під безпосереднім керівництвом їх командувачів, виникає проблемне питання - підвищення ефективності системи ППО угруповання військ за рахунок зниження ефективності системи ППО держави, як наслідок - загальна ефективність операції ЗС теж знижується. Особливо зміни в угрупованнях військ впливають на систему управління. Здійснюється іï ускладнення за рахунок збільшення об'єктів управління, розгортання додаткових (проміжних) ПУ, розпорошення фахівців ППО оперативної ланки, ускладнення системи зв'язку та збільшення обігу потоків інформації. Як наслідки - погіршення оперативності, організації взаємодії, маневреності, прихованості дій[8-12]. Загальний наслідок - зменшення ефективності виконання завдань оперативного та стратегічного рівня.

Раніше автономність у діях військ і сил ППО різних видів ЗС в певній мірі компенсувалася досить великим кількісним складом сил та засобів. В дійсний час, в умовах жорстких фінансових обмежень i оптимізації чисельності Збройних Сил, цей шлях підвищення ефективності протиповітряної оборони став неможливим.

Головна вимога щодо управління військами, наявними у них силами та засобами ППО - забезпечити повне використання їх потенційних можливостей в інтересах успішного і своєчасного виконання поставлених перед ними завдань, як в мирний (на етапі підготовки), так і у воєнний час (під час виконання завдань за призначенням). Виконання цієї вимоги можливо через виконання часткових вимог, що складають проблемні питання.

Додаткові вимоги пропонується розподілити на напрямки:

вимоги до системи управління (організаційнотехнічна складова) - забезпечення постійної готовності до функціонування, стійкість, прихованість; вимоги до управління військами (у частині цілеспрямованої діяльності органів управління) - якість, безперервність i оперативність. Так як організаційнотехнічну основу управління складає система управління, розглянемо шляхи іiї вдосконалення за ії складовими елементами, які на протязі останніх заходів реформування постійно підпадали під “експерименти" з нульовим або негативним результатом:

вдосконалення організаційно-штатних структур органів управління;

вдосконалення складу i структур пунктів управління.

Безсумнівно, що для роботи в цих напрямках необхідно чітко бачити тенденції, фактори, які здійснюють негативний вплив.

Негативні тенденції, фактори, які здійснюють вплив $\epsilon$ наслідками сучасних змін, які здійснюються у підготовці і веденні бойових дій, міжвидових операцій.

По-перше, все більш вирішальне значення набуває фактор часу, який визначається можливостями сучасних засобів повітряного нападу (ЗПН), швидкодією сучасної зброї, зростанням мобільності військ, їх здатність, в короткі терміни приводитись у готовність до бою, швидко здійснювати маневр і як наслідок, раптово завдавати удари.

По-друге, постійно збільшується обсяг управлінських робіт, пов'язаний з появою ряду нових заходів по управлінню визначеними силами та засобами різнорідних суб'єктів що залучаються до ППО.

Збільшилась кількість необхідної інформації в ході управління військами, що обумовлено великим просторовим розмахом бойових дій, різноманітністю застосовуваних бойових засобів, збільшенням кількості об'єктів управління, різкими змінами обстановки, обмеженість у часі на формування та здійснення управлінського впливу.

По-третє, зростає вимогливість до змісту та повноти рішень, які повинні спиратися не тільки на інтуїцію і досвід командира, але, перш за все, на чіткі розрахунки, об'єктивну кількісно-якісну оцінку можливостей сторін і оперативне прогнозування.

По-четверте, збільшуються можливості сил i засобів розвідки і поразки ЗПН противника, що збільшує вимогливість до прихованого управління i забезпечення безперервності управління на великій відстані у реальному масштабі часу.

Виходячи з вищезазначеного, проблемними питаннями управління протиповітряною обороною $є$ : 
проблема виграшу часу, тобто підвищення оперативності управління;

проблема розрахункового обгрунтування прийнятих рішень і оптимізація планування;

проблема забезпечення скритності і безперервний контроль (формування управлінського впливу).

Умови ведення сучасних і перспективних бойових дій вимагають перш за все уточнити існуючі принципи управління військами.

Потрібує уточнення принципу “централізації управління", з наданням підлеглим ініціативи у визначенні способів виконання поставлених перед ними завдань.

На даний час бойові завдання військам ставляться зверху вниз по підпорядкованості. Отримавши бойове завдання, командир, згідно з вимогами наших статутних документів, зобов'язаний прийняти рішення про способи виконання бойового завдання $\mathrm{i}$ доповісти його своєму начальнику і тільки після затвердження замислу він може поставити завдання своїм підлеглим. Так відбувається на кожному рівні системи управління (командній інстанціі). Подібний порядок значно подовжує цикл управління, що в умовах ведення протиповітряних, повітряних бойових діях, знижує оперативність управління та знімає відповідальність 3 командира нижчої ланки, адже рішення затверджено старшим начальником, тобто відбувається порушення принципів “надання підлеглим ініціативи ...” і “ відповідальності за правильне застосування підпорядкованих військових частин.

Ще більше збільшення циклу управління відбувається при плануванні бойових дій застарілими методами. Особливо наочно це відбувається при плануванні вогневого ураження противника та плануванні взаємодії. Існуюча організація роботи з планування займає дуже багато часу і часто не відповідає швидкоплинності змін обстановці.

Варіантом зменшення терміну проведення циклу управління $\epsilon$ :

перегляд кількості та змісту планувальних, розпорядчих документів на кожному управлінському рівні;

перехід до спільного принципу планування, за рахунок залучення оперативних груп від взаємодіючих органів військового управління інших видів 3С на ПУ, у перспективі створити штатні структурні підрозділи на ПУ з представниками.

Це дозволить підвищити оперативність управління, а значить і його ефективність.

Поряд з методами послідовної, паралельної роботи та їх поєднанням, перспективним є метод спільної роботи по виробленню замислу операції (бою). Цей метод передбачає участь підлеглих командирів у виробленні задуму. Такий метод широко використовується, коли замисел бою виробляється на нараді за участю командирів об'єднань, військових частин. При сучасних і перспективних засобах управління такий метод можливий без безпосеред- нього виклику підлеглих командирів на КП старшого начальника, i забезпечить чітке розуміння всіма підлеглими командирами замислу свого начальника, місце і роль свого об'єднання (частини, підрозділу) в операції (бою), полегшить підтримку взаємодії.

Потрібує уточнення принципу “плановості ведення бойових дій”. В останній час деталізація при плануванні перевищила рівень необхідності. Планування у штабі виду здійснюється 3 деталізацією до батальйону, дивізіону, окремого радіолокаційного взводу. Як наслідок - органи управління перевантажені розробкою всіляких планів із зайвою деталізацією і це часто є причиною неузгодженості як самих планів, так і дій частин. Як варіант, необхідно виходити з вимоги спрощення планування, бо тільки простий і ясний планувальний документ, чіткі накази і розпорядження зменшує можливість неправильного розуміння завдань і полегшать їх виконання.

Діяльність органів управління можливо поділити на два основних виду: аналітично - планувальна (прогностична) та інформаційно-розрахункова.

Аналітично - планувальна (прогностична) діяльність - головний вид діяльності в управлінні.

Інформаційно-розрахункова діяльність - допоміжна, вона призначена забезпечити головний вид діяльності.

За обсягом трудовитрат інформаційно-розрахункова діяльність в даний час займає близько $80 \%$ трудовитрат органів управління і лише близько $20 \%$ припадає на аналітично - планувальну діяльність. Така різниця в трудовитратах не відповідає вимогам до організації управління. Дослідження показують, що для здійснення ефективного управління підпорядкованими військовими частинами, в сучасних умовах, необхідно час на інформаційну діяльність органів управління скоротити до 15-20\% і вивільнити час для творчої та організаторської діяльності до 80-85\%. Досягти цього неможливо без впровадження в методи і зміст роботи органів управління нових інформаційних технологій, уніфікації процесів (стандартних процедур). Перейти до технології інформаційних мереж, систем автоматизованого моделювання, обробки інформації (прийняття рішення, планування), нових технічних засобів збору, обробки, зберігання, передачі та відображення інформації.

Вирішення цієї проблеми слід шукати в:

упорядкуванні потоку інформації;

виробленні науково-обгрунтованих методів прийняття рішення і планування операції (бою);

систематизації методик оперативно-тактичних розрахунків;

застосуванні засобів автоматизації при розробці бойових документів;

переході до без паперової інформаційної технології;

зниження дублювання інформації;

створення бібліотек даних (електронних баз) 3 автоматизованого управління військами 3 можливістю коригування планів бойового застосування військ; 
можливості забезпечення автоматизованого контролю за виконанням прийнятих рішень (розроблених планів) 3 видачею результатів порівняння реальних дій військ (сил) з очікуваними відповідно до розроблених планів;

забезпеченні здійснення автоматизованого контролю за збором даних обстановки з видачею попередження про дані які не надійшли до даного часу;

підвищенні рівня автоматизації (за рахунок використання математичних моделей) 3 вироблення рекомендацій на раціональне застосування сил і засобів при різних варіантах дій противника, моделюванні бойових дій, розробці планів бойового застосування військ, доведення до них бойових завдань в автоматизованому режимі.

Щодо діяльності органів управління. Досвід бойових дій, оперативної та бойової підготовки свідчить, що існуючі органи управління забезпечують керівництво військами в основному в мирний час, проте не в повній мірі відповідають обсягу та характеру покладених на них завдань у воєнний час. Для більшості органів управління характерна суттєва перебудова їх структури при переході на бойовий режим роботи. При цьому відбувається перерозподіл особового складу по структурним підрозділам, його часткове перепідпорядкування і зміна функціональних обов'язків. Ця перебудова необхідна для створення органів управління 3 планування і організації управління. Це актуально для групи загального планування, групи планування вогневого ураження, групи напрямків, центру інформації і ін. Як наслідок, необхідність проведення злагодження органів управління в умовах дефіциту часу. Крім того, при виконанні завдань в інтересах міжвидового угруповання військ, або декількох угруповань, потрібне створення додаткових структурних підрозділів у складі ПУ Командування ПС, повітряного командування 3 представниками органів управління військами різних відомств. Все це не забезпечує випереджаючої готовності органів управління по відношенню до бойової готовності військ. Відмінності в організаційно-штатних структурах органів управління мирного і воєнного часу негативно позначаться на управлінні військами при переведенні їх на військовий стан i, особливо, на початку війни. Як варіант, основний напрямок вдосконалення органів управління - створення штатних органів для підготовки військ і керівництві ними в ході бою. Це перш за все: штатні органи загального планування, планування та управління вогневим ураженням противника, інформації та інші. В основі визначення чисельності органів управління та їх структурних підрозділів головним показником враховувати той обсяг управлінських завдань, що цей орган може виконати даними складом в певний проміжок часу. Зміна ж обсягу і трудомісткості завдань повинно взаємопов'язуватись 3 чисельністю структурних підрозділів. Необхідно провести уточнення функціональних обов'язків з метою виключення дублювання однієї і тієї ж роботи, підвищувати продуктивність праці за рахунок вдосконалення засобів управління і методів роботи. Важливим фактором, що впливає на чисельність органів управління, $€$ норми керованості посадових осіб (кількість підлеглих, діяльністю яких може ефективно управляти один керівник в певних умовах). В даний час при сучасних засобах управління такий рівень може становити: для командувачів (командирів) в оперативній ланці - 4-6, в тактичній ланці - 4-7 об'єктів управління, для начальника штабу, в оперативній ланці - 5-7, в тактичній ланці 6-8 об'єктів управління [8-10].

Одним із слабких місць організаційно-штатної структури існуючих органів управління $є$ їх штатна чисельність, яка, як правило, недостатня для вирішення оперативним складом завдань на всіх пунктах управління (особливо в управлінні ПвК і бригадній (полковій) ланці). Особовий склад штатно за пунктами управління не закріплений і визначається бойовим розрахунками. Частина покладених на органи управління завдань вирішується позаштатними оперативними (робочими) групами, як правило, в належній мірі не забезпеченими коштами управління. Велика частина оперативного складу виділяється для роботи на ПУ, що розгортаються та на взаємодіючи. Оперативний склад ЗКП за чисельністю, якістю i можливостям поступається оперативному складу КП в 3 - 4 рази, при необхідності він не може без додаткового посилення своєчасно взяти на себе i виконати завдання управління військами.

Аналіз існуючого порядку отримання, обробки і передачі інформації свідчить про нераціональне розподілі інформаційного потоку в органах управління. Внаслідок нерівномірного розподілу потоку інформації відбувається нераціональна завантаження різних засобів прийому та передачі інформації, що знижує оперативність управління. Значна частина робочого часу (до 35\%) висококваліфіковані фахівці органів управління витрачають на виконання не властивих їм функцій з передачі, зчитування, редагування i іншим діловодних операцій. Ефективність управлінської діяльності також знижується і за рахунок значного документообігу, не передбаченого керівними документами (до 30\%). Внаслідок цього, керівний склад, офіцери штабу, чергові зміни КП перевантажені зайвою інформацією. Для вирішення цих проблем протягом останніх років до організаційно-штатної структури органів управління, вносяться зміни. Йде робота по пошуку оптимальної структури до штатних робочих груп ПУ та управлінь військових частин, перш за все груп які відповідають за здійснення загального планування і планування вогневим ураженням противника. Але загальною тенденцією скорочення чисельності управлінського апарату штабів оперативної та оперативно-тактичної ланки є зменшення чисельності офіцерів-операторів, що має негативні наслідки.

Загальну ефективність ППО у визначених межах зон відповідальності угруповання ПС можливо 
значно підвищити за рахунок реалізації оперативного управління всіма військами, силами та засобами ППО, шляхом:

по-перше, зосередження зусиль на основі єдиного задуму і плану для вирішення найбільш важливих завдань;

по-друге, інтегрування та узгодження дій різновидових військ і сил, засобів ППО.

При цьому бойовий потенціал всіх військ, сил і засобів ППО розподіляється в залежності від ступеня загрози об'єктам оборони та їх важливості. Пріоритетність об'єктів, що обороняються доцільно визначати на кожен момент ведення військових дій (операцій, бойових дій) відповідно до ступеня їх важливості в зоні (районі) ППО. Принцип оборони по пріоритетності об'єктів не поширюється на штатні формування ППО частин і з'єднань Сухопутних військ, а також флотські зенітні вогневі засоби (досвід заходів оперативної підготовки). Вони безпосередньо підпорядковуються своїм командирам i діють в бойових порядках своїх військ (сил), проте оперативне (бойове) керування ними при відображенні ударів ЗПН в тій чи іншій мірі має здійснюватися з командних пунктів ППО (ЦУО, ОКП ПвК).

Застосування запропонованого підходу піднімає проблему визначення ступеня важливості об'єктів.

Один бік якої пов'язаний $з$ відповіддю на непросте питання: що важливіше, наприклад, військово-морська база, атомна електростанція, адміністративно-політичний центр або угруповання Сухопутних військ?

Визначення важливості об'єктів протиповітряної оборони, доцільно грунтувати на поєднанні аналітичних розрахунків та експертних оцінок, що дозволять досить впевнено відповісти на нього.

Інше питання: в чиїй це компетенції? Очевидно, визначенням важливості об'єктів повинні займатися безпосередньо Командування ПС ЗС України, повітряні командування у взаємодії з штабами, командуваннями інших видів 3С.

Об'єктивне рішення даної задачі можливе тільки на основі як єдиного керівництва всіма військами і силами ППО, так і єдиної відповідальності командування за оборону об'єктів держави зоні відповідальності ППО.

Як показують дослідження, приріст ефективності дій військ і сил ППО різних видів $3 \mathrm{C}$ і родів військ за рахунок комплексування і узгодження їх дій може досягати 40-60\%. Він забезпечується взаємною компенсацією слабких сторін одних угруповань військ (сил) сильними сторонами інших, зосередженням зусиль на знищенні найбільш важливих (небезпечних) засобів повітряного нападу і їх груп, а також зменшенням втрат авіації від вогню своїх зенітних ракетних засобів [3].

Комплексування і узгодження дій військ і сил ППО можливо тільки при централізованому оперативному (бойовому) управлінні ними. Отже, єдине централізоване оперативне управління повинно ор- ганізовуватися для всіх без винятку військ, сил і засобів ППО. Саме ця обставина зазвичай викликає заперечення через сумнівів в можливості управління великою кількістю засобів ППО малої дальності, наявних в з'єднаннях Сухопутних військ та на кораблях флоту.

Однак дослідження і досвід країн НАТО свідчать про те, що така можливість реальна, якщо перейти на нові принципи управління і побудови системи управління, управляти в зонах відповідальності ППО не окремими засобами, а силами. При цьому кожне з'єднання (частина), що потрапляє під визначену зону відповідальності ППО, підключається до інформаційної та командної систем, керуючий орган починає враховувати їх положення і бойові можливості (просторові, часові та вогневі), виробляє рішення і ставить завдання на дії, які узгоджуються 3 діями інших з'єднань (частин) ППО.

\section{Висновки}

Таким чином, на сьогоднішній час теорія та практика в організації протиповітряно оборони під час проведення операції ЗС мають протиріччя, які впливають на ефективність застосування військ.

Одні з основних шляхів їх вирішення є:

визначення порядку управління протиповітряною обороною у ході ведення операції 3С;

визначення оптимальної структури системи пунктів управління силами та засобами ППО у єдиній системі управління 3С та удосконалення структури органів управління;

оптимізація обігу інформації під час управління ППО.

Запропоновані шляхи удосконалення потребують подальшого дослідження щодо визначення та обгрунтування рекомендацій по підвищенню ефективності управління протиповітряною обороною, особливо у ході ведення операції ЗС України.

Саме рішення вищеназваних проблемних питань сприятиме забезпеченню високої ефективності управління військами і зброєю.

\section{Список літератури}

1. Указ Президента України №73/2017 “Про рішення національної безпеки і оборони України від 29 грудня 2016 року "Про Державну програму розвитку збройних сил Украӥни на період до 2020 року".

2. Загорка О.М. Аналіз підходів для визначення доиільних форм $i$ способів бойових дій угруповань військ (сил) / О.М. Загорка, Р.І. Тимошенко, І.О.Загорка // Збірник наукових праць Центру воєнно-стратегічних досліджень Національного університету оборрони Украӥни імені Івана Черняховського. - 2015. - № 1 (53). - C. 7-12.

3. Петров В.М. Проблеми оперативного мистеитва Повітряних Сил Збройних Сил Украӥни / В.М Петров, I.M. Тіхонов, О.В. Заболотний // Збірник наукових праць Харківського університету Повітряних Сил. - 2016. - № 4 (49). - C. 35-37.

4. Щипанський П.В. Напрялки розвітку родів авіаиії та родів військПовітряних Сил в перспективній структурі Збройних Сил України / П.В. Щипанський, О.В. Пу- 
ховий, Г.С. Степанов // Збірник наукових працьь Центру воєнно-стратегічних досліджень Національного університету оборрони Украӥни імені Івана Черняховського. 2014. - № 2 (51). - C. 83-88.

5. Степанов Г.С. Досвід іноземних держав щзоо здійснення прикриття обєктів від можсливих терористичних атак (актів) з повітря при проведенні заходів Г.С. Степанов // Наука і техніка Повітряних Сил Збройних Сил Украӥни. - 2012. - № 1 (27). - С. 17-20.

6. Кларк Р. Третья мировая война: какой она будет? / Р. Кларк, Р. Нейк ; перс англ. Е Карманова. СПб.: Питер, 2011.

7. Барабаш О.В. Трансформация положений теории Джона Уордена в современных условиях вооруженной борьбьл / О.В.Барабаш, С.Ю. Мухин, О.Н. Горский, Ю.К.Мирошниченко// Первый независимый научный вестник. - Киев, 2017. - №22. - С.8-12.

8. Ткаченко В. І. Проблема "міжвидовості" та шляхи ї̈ вирішення / В. І. Ткаченко, С. Б. Смірнов // Наука і техніка Повітряних Сил Збройних Сил Украйни. - 2013. - № 2. - C. 41-48.

9. Піскунов С. М. Перспективна структура системи управління силами та засобами протиповітряної оборони сухопутних військ / С. М. Піскунов // Збірник наукових прачь Харківського начіонального університету Повітряних Сил. - 2013p. - № 2 (35). - С. 6-10.

10. Нізієнко Б.I. Аспекти удосконалення системи управління протиповітряною обороною Украӥни / Б.І. Нiзієнко, С.А. Юхновський, С.А. Макаров // Наука і техніка Повітряних Сил Збройних Сил Украӥни. - Харків, 2017. № 1 (26). - C. 17-20

11. Алимпиев В.А. Існуюча система ППО в зоні відповідальності ПвК, перспективи развитку, система ППО майбутнього/ В.А.. Алімпієв, В.О. Курочкін, С.П. Мазін // Новітні технології для захисту повітряного простору: зб. Тез доповідей Тринадиатої наукової конферениії Харківського начіонального університету Повітряних Сил імені Івана Кожедуба. 12 - 13 квітня 2017p. - Харків, 2017 C. 26 .

12. Генов Б.А. Проблемні питання та можливі наапрямки підвищення ефективності організації міжвидовоі взаємодї під часвиконання завдань за призначенням /
Б.А.Генов, А.О. Бережний // Новітні технології для захисту повітряного простору: зб. Тез доповідей Тринадияатої наукової конференциї Харківського начіонального університету Повітряних Сил імені Івана Кожедуба. 12 - 13 квітня 2017p. - Харків, $2017-$ - С.27.

13. Шинкарьов С.М. Методичний підхід до оичінки ефективності системи управління противоздушною обороною / С.М. Шинкарьов, В.П.Городнов, С.В. Лазебник, О.Н. Мисюра // Збірник наукових праць Харківського наиіонального університету Повітряних Сил. - 2017. - № 2 (51). - C. 25-27.

14. Загорка О.М.. Особливосты та принципи побудови мережочентричної системи управління угруповання військ (сил) / О.М. Загорка, В.В. Коваль, В.В. Тюрін, В.Г. Малюга, І.О. Загорка // Збірник наукових пращь Харківського національного університету Повітряних Сил. 2016p. - № 3 (48). - C. 7-11.

15. Ермошин М.О. Основні показники для оцінки ефективності функиіонування системи протиповітряної оборони / Срмошин М.О // Збірник наукових праџь Харківського начіонального університету Повітряних Сил. 2008p. - № 2 (17). - C. 14-16.

16. Пунда Ю.В. Проблеми відповідності системи управління Збройними Силами України умовам гібридноі війни / Ю.В. Пунда, С.І. Антоненко // Сучасні інформаційні технології у сфері безпеки та оборони. Національний університет оборрони Украӥни імені Івана Черняховського. - Київ 2017. - № 21 (28). - С. 120.

17. Алимпиев В.А. Існуюча система ППО в зоні відповідальності ПвК, перспективи развитку, система ППО майбутнього/ В.А. Алімпієв, В.О. Курочкін, С.П. Мазін // Новітні технології для захисту повітряного простору: зб. Тез доповідей Тринадиатої наукової конференциї Харківського начіонального університету Повітряних Сил імені Івана Кожедуба. 12 - 13 квітня 2017p. - Х., 2017 - С.26.

Надійшла до редколегії 25.12.2017

Рецензент: канд. техн. наук, проф. Б.І. Нізієнко, Харківський національний університет Повітряних Сил імені Івана Кожедуба, Харків.

\title{
ПРОБЛЕМЫ ВЫБОРА УПРАВЛЕНИЯ ПРОТИВОВОЗДУШНОЙ ОБОРОНОЙ ВО ВРЕМЯ ПРОВЕДЕНИЯ ОПЕРАЦИИ ВООРУЖЕННЫХ СИЛ
}

\author{
А.Н. Луцишин, Г.С. Степанов, И.А. Костюк
}

В статье рассмотрены проблемные вопросы порядка организации управления противовоздушной обороною Украины в ходе выполнения задач межвидовыми группировками войск в ходе операчии вооруженных сил, причины их появления и воздействие на эффективность управления противовоздушной обороной. Рассмотрено пути решения их и предложены направления для дальнейшего исследования с иелью обоснования рекомендаций по повышению эффективности управления противовоздушной обороной в ходе проведения операции вооруженных сил.

Ключевые слова: управление, противовоздушная оборона, система управления, эффективность управления, важные государственные объекты, критические объекты государства, органы управления, пункты управления противовоздушной обороной.

\section{PROBLEM MANAGEMENT AIR DEFENCES DURING THE OPERATION OF THE ARMED FORCES}

A.M. lutsyshyn, G.S. Stepanov, I.A. Kostiuk

In the article a role and place of air defense in the system of strategic actions and her influence are considered on providing of defensive capacity of the state. Indicated problem questions that influence on organization and conduct of air defense. Contradiction of the existent theoretical going is considered near organization of management air defense of Ukraine with practical possibilities of her realization. The feature of question that is examined in the article is realization of air defense during the strategic operation of the armed forces, that has complex character of realization in basis of that simultaneous application of interspecific groupments of troops constrained is fixed by an only strategic aim. Reasons of their origin and influence are on efficiency of management air defense. The ways of their decision and certain directions are considered for further research with the aim of ground of recommendations on the increase of efficiency of management air defense during the conduct of operation of $3 C$ without the decline of efficiency of the system air defense of the state.

Keywords: management, air defence management system, management efficiency, important government facilities, critical state objects, controls, control points antiaircraft defense. 